JURNAL SEHAT MASADA $\quad$ VOLUME $\quad$ XV NOMOR $1 \quad$ Januari $2021 \quad$ ISSN : 1979-2344

\title{
FAKTOR-FAKTOR YANG MEMPENGARUHI TERJADINYA PREEKLAMPSIA PADA IBU BERSALIN DI RSUD MUHAMMAD SANI KARIMUN TAHUN 2018
}

\author{
Prasida Yunita \\ Program Studi Kebidanan Fakultas Kedokteran Universitas Batam \\ ita_bugz@yahoo.com
}

\begin{abstract}
Preeklamsia dan eklamsia diperkirakan menjadi penyebab utama kematian ibu dari $14 \%$ ibu yang melahirkan per tahun, yang pada saat yang sama juga dikaitkan dengan tingginya angka kematian ibu dan bayi serta angka morbiditas. Merujuk pada data RSUD Muhammad Sani Karimun bahwa 102 bayi lahir dengan persalinan normal, sedangkan 574 persalinan lainnya melalui operasi caesar dan juga 38 persalinan dengan persalinan vakum. Dari total persalinan yang disebutkan, terdapat 121 kasus preeklamsia dan 10 kasus eklamsia. Tujuan penelitian ini adalah untuk mengetahui faktor-faktor potensial pemicu terjadinya preeklamsia selama persalinan. Penelitian ini merupakan penelitian kuantitatif dengan desain survey analitik case control. Populasi dalam penelitian ini adalah 218 ibu bersalin di RSUD Muhammad Sani Karimun tanggal Januari sampai Maret 2018 dengan jumlah sampel 60 responden. Hasil penelitian menunjukkan 37 responden $(61,7 \%)$ berusia $<20$ tahun atau $>35$ tahun mengalami preeklamsia, 56 responden $(93,3 \%)$ pernah hamil tunggal, 57 responden $(95 \%)$ tidak mengalami diabetes, dan 31 responden $(517 \%)$. ) adalah ibu paritas dengan preeklamsia kecil. Dari temuan tersebut disimpulkan bahwa umur dan paritas berhubungan dengan kejadian preeklamsia, sedangkan kehamilan kembar dan diabetes tidak berhubungan dengan kejadian preeklamsia. Terakhir, disarankan bagi peneliti selanjutnya untuk menggunakan metode penelitian lain seperti kualitatif dan menambahkan lebih banyak variabel seperti mola hidatidosa atau jarak kebuntingan dalam penelitian selanjutnya.
\end{abstract}

Kata kunci : Usia, Paritas, DM, Preeklamsi

\begin{abstract}
Preeclampsia and eclampsia are estimated to be the major causes of maternal death of $14 \%$ laboring mothers per year,in which at the same time, are also associated with high neonatal and maternal mortality as well as morbidity rates. Referring to the data of the RSUD Muhammad Sani Karimun that 102 babies were born with normal delivery, whereas the other 574 births were through $C$-section surgery andthere also 38 deliveries with vacuum labor. From the total of all deliveries stated, there were 121 cases of preeclampsia and 10 cases of eclampsia. The purpose of this study is to investigate the potential factors that trigger the occurrence of preeclampsia during labors. This study is a quantitative research with analytic survey of case control design. The population of this study was 218 laboring mother in Muhammad Sani Karimun Hospital dated from January to March 2018 with a total sample of 60 respondents. The result shows 37 respondents $(61.7 \%)$ aged $<20$ years or $>35$ years experienced preeclampsia, 56 respondents (93.3\%) had single pregnancy, the other 57 respondents (95\%) did not experience diabetes, and 31 respondents (51 7\%) were parity mothers with small preeclampsia. Form the findings, it is concluded that age and parity are associated with the incidence of preeclampsia, while multiple pregnancies and diabetes are not associated with the incidence of preeclampsia. Finally, it is suggested for future researchers to use other research method such as qualitative and to add more variables such as hydatidiform mole or pregnancy distance in their future research.
\end{abstract}

Keywords : Age, Pragnancy, DM, Preeklamsi 


\section{PENDAHUluaN}

Data World Health Organization (WHO) tahun 2007-2016, menyatakan bahwa kematian ibu di dunia mencapai 342.900 kematian setiap tahunnya dan diiringi sepertiga kematian neonatal. Laporan kesehatan dunia menyatakan bahwa ada sekitar 287.000 kematian ibu pada tahun 2010 yang terdiri atas Afrika Sub-Sahara (56\%) dan Asia Selatan (29\%) atau sekitar 85\% (245.000 kematian ibu) terjadi di negara berkembang. Sedangkan di negara-negara Asia Tenggara yaitu 150 ibu per 100.000 kelahiran hidup (Christina, 2013).Indonesia berada pada peringkat ke-14 dari 18 negara di Association of Southeast Asian Nations (ASEAN) dan peringkat ke-5 tertinggi di South East Asia Region (SEARO) (Hukmiah dkk, 2013).

Angka Kematian Ibu (AKI) masih menjadi salah satu masalah kesehatan ibu dan anak di Indonesia.Tingginya AKI di Indonesia yakni mencapai 359 per 100.000 Kelahiran Hidup (KH) (SDKI, 2012).

Komplikasi kehamilan berpengaruh terhadap kematian ibu dengan odds ratio (OR) sebesar 12,189 apabila variabel komplikasi persalinan dan riwayat penyakit dibuat konstan (dikontrol), ibu yang mengalami komplikasi kehamilan berisiko mengalami kematian 12,198 kali lebih besar daripada ibu yang tidak mengalami komplikasi kehamilan. Sedangkan komplikasi persalinan berpengaruh terhadap kematian ibu dengan OR sebesar 9,94. Adapun jenis komplikasi sebagai penyebab langsung terjadinya kematian ibu adalah perdarahan $28 \%$, eklampsia $24 \%$, infeksi $11 \%$, dan komplikasi kehamilan lain 15\% (Afdhal dkk, 2012). Ibu yang mengalami komplikasi pada kehamilan cenderung mengalami komplikasi pada persalinannya 2,15 kali dibandingkan ibu yang tidak mengalami komplikasi pada kehamilannya $(\mathrm{OR}=2,15$; 95\% CI 1,81-2,54) (Armagustini, 2010).

Di Indonesia eklampsia di samping perdarahan dan infeksi masih merupakan sebab utama kematian ibu, dan sebab kematian perinatal yang tinggi. Oleh karena itu, diagnosis dini Preeklampsia yang merupakan tingkat pendahuluan eklampsia, serta penanganannya perlu segera dilaksanakan untuk menurunkan angka kematian ibu dan anak (Prawiroharjo, 2012).

Berdasarkan Survei Demografi Kesehatan Indonesia (SDKI) tahun 2012, penyebab langsung AKI di Indonesia antara lain: perdarahan 42\%, eklampsia/preeklampsia $13 \%$, abortus $11 \%$, infeksi $10 \%$, partus lama 9\%, dan penyebab lain $15 \%$ (SDKI, 2012). Menurut Djannah (2010), kejadian preeklampsia pada negara berkembang berkisar antara 0,3 persen sampai 0,7 persen, sedangkan pada negara maju angka preeklampsia lebih kecil yaitu berkisar antara 0,05 persen sampai 0,1 persen. Di Indonesia preeklampsia berat dan eklampsia merupakan penyebab kematian ibu 1,5 persen sampai 25 persen, sedangkan kematian bayi antara 45 persen sampai 50 persen (Djannah, 2010).

Berdasarkan data audit maternal Kabupaten Karimun tahun 2017, jumlah kematian ibu sebanyak 13 orang yang terdiri 
JURNAL SEHAT MASADA VOLUME XV

dari 2 orang kematian disebabkan perdarahan $(15,38 \%), 6$ orang kematian disebabkan oleh hipertensi dalam kehamilan $(46,15 \%), 1$ orang kematian disebabkan infeksi $(7,69 \%), 1$ orang kematian disebabkan gangguan organ peredaran darah $(7,69 \%), 3$ orang kematian disebabkan lain-lain $(23,07 \%)$.

Berdasarkan data dari RSUD Muhammad Sani Karimun tahun 2017, jumlah persalinan normal sebanyak 102 persalinan dan jumlah sectio secarea sebanyak 574 persalinan. Selain itu jumlah pasien persalinan dengan vacum yaitu 38 persalinan dan induksi sebanyak 121 orang. Dari total seluruh persalinan yang ada, pasien yang terdiagnosa preeklampsia yaitu sebanyak 121 orang dan 10 orang eklampsia pada tahun 2017.

Berdasarkan latar belakang di atas, peneliti tertarik membahas masalah mengenai "Faktor-faktor yang Mempengaruhi Terjadinya Preeklampsia pada Ibu Bersalin di RSUD Muhammad Sani Karimun Tahun 2017”

Tujuan pelaksanaan penelitian adalah :

- Untuk mengetahui distribusi frekuensi kejadian preeklampsiadi RSUD Muhammad Sani Karimun Tahun 2018.

- Untuk mengetahui distribusi frekuensi ibu bersalin dengan preeklampsia berdasarkan usiadi RSUD Muhammad Sani Karimun Tahun 2018.

- Untuk mengetahui distribusi frekuensi ibu bersalin dengan preeklampsia berdasarkan paritas di RSUD Muhammad Sani Karimun Tahun 2018.

- Untuk mengetahui distribusi frekuensi ibu bersalin dengan preeklampsia berdasarkan Jurnal Penelitian Kesehatan STIKes Dharma Husada Bandung kehamilan ganda di RSUD Muhammad Sani Karimun Tahun 2018.

- Untuk mengetahui distribusi frekuensi ibu bersalin dengan preeklampsia berdasarkan diabetes di RSUD Muhammad Sani Karimun Tahun 2018.

- Untuk mengetahui hubungan antara preeklampsia dengan usia pada ibu bersalin di RSUD Muhammad Sani Karimun Tahun 2018.

- Untuk mengetahui hubungan antara preeklampsia dengan paritas pada ibu bersalin di RSUD Muhammad Sani Karimun Tahun 2018.

- Untuk mengetahui hubungan antara preeklampsia dengan kehamilan ganda pada ibu bersalin di RSUD Muhammad Sani Karimun Tahun 2018.

- Untuk mengetahui hubungan antara preeklampsia dengan diabetes pada ibu bersalin di RSUD Muhammad Sani Karimun Tahun 2018.

\section{METODE PENELITIAN}

Jenis penelitian yang digunakan adalah survey analitik dengan menggunakan pendekatan case control atau kasus kontrol yaitu suatu penelitian dengan cara membandingkan antara kelompok kasus dan kelompok kontrol berdasarkan status paparannya (retrospective) arah pengusutannya, rancangan tersebut bergerak dari akibat (penyakit) ke sebab (paparan). 
Penelitian ini dilakukan pada bulan Maret-Juli 2018.Penelitian ini dilakukan diRSUD Muhammad Sani Karimun.

Populasi pada penelitian ini adalah populasi kelas kasus ibu bersalin di RSUD Muhammad Sani Karimun tahun 2018 sejumlah 218 orang. Jumlah kejadian preeklampsia 30 orang. Jumlah kasus yang akan digunakan yaitu 2 (dua) kali dari jumlah kasus yaitu sebanyak 60 orang.

\section{HASIL DAN PEMBAHASAN}

\section{a. Hasil}

Analisis ini untuk memperoleh distribusi frekuensi masing-masing variabel dependen (usia, kehamilan ganda, diabetes dan paritas) serta variabel independen (preeklampsia).Data disajikan dalam bentuk tabel distribusi frekuensi.

\section{1) Analisa Univariat}

Diketahui bahwa dari 60 responden pada penelitian ini didapatkan bahwa sebagian besar responden berusia $\leq 20$ tahun atau $>35$ tahun sebanyak 37 orang $(61,7 \%)$. Sebagian besar responden mengalami kehamilan tunggal sebanyak 56 orang $(93,3 \%)$. Sebagian besar responden tidak mengalami diabetes sebanyak 57 orang $(95 \%)$ dan sebagian besar responden mengalami paritas dalam jumlah yang sedikit $(\leq 2)$ sebanyak 31 orang $(51,7 \%)$.

\section{2) Analisis Bivariat}

Analisis bivariat dilakukan untuk mengetahui hubungan antara variabel independen dan variabel dependen.

\section{a) Hubungan Usia Terhadap Preeklampsia}

Dari jumlah total sebanyak 37 responden dengan usia $<20$ atau $>35$ tahun yang mengalami preeklampsia yaitu sebanyak 14 responden (37,8\%). Sedangkan dari 16 responden dengan usia 20-35 tahun, yang mengalami preeklampsia yaitu sebanyak 16 responden $(69,6 \%)$. Hasil uji statistik chi square, diperoleh $\mathrm{p}$ value $=0,004$ artinya $\mathrm{p}$ value kecil dari 0,05 maka Ho gagal ditolak dengan demikian menunjukan bahwa ada hubungan yang signifikan antara usia dengan kejadian preeklampsia di RSUD Muhammad Sani Karimun.

Nilai PrevalensiOdds Ratio $(\mathrm{POR})=$ 5,266 dengan nilai Confidence Interval 95\% $(C I)=2,088-11,807$ artinya responden dengan usia berisiko 5,2 kali berpeluang mengalami preeklampsia dari pada responden dengan usia tidak berisiko.

\section{b) Hubungan Kehamilan Ganda Terhadap Preeklampsia}

Dari jumlah total sebanyak 56 responden dengan kehamilan tunggal, yang mengalami preeklampsia yaitu sebanyak 28 responden (50\%).Sedangkan dari 4 responden dengan kehamilan ganda, yang mengalami preeklampsia yaitu sebanyak 2 responden (50\%).Hasil uji statistik chi square, diperoleh $\mathrm{p}$ value $=1,000$ artinya $\mathrm{p}$ value besar dari 0,05 maka Ho ditolak dengan demikian menunjukan bahwa tidak ada hubungan yang signifikan antara kehamilan ganda dengan kejadian preeklampsia di RSUD Muhammad Sani Karimun. 
Nilai PrevalensiOdds Ratio $(\mathrm{POR})=$ 1,000 dengan nilai Confidence Interval 95\% $(\mathrm{CI})=0,131-7,605$ artinya responden dengankehamilan ganda berisiko 1 kali berpeluang mengalami preeklampsia dari pada responden dengan usia kehamilan tunggal.

\section{c) Hubungan Diabetes Terhadap Preeklampsia}

Dari jumlah total sebanyak 3 responden dengan diabetes yang tidak mengalami preeklampsia yaitu sebanyak 3 responden (100\%). Sedangkan dari 57 responden yang tidak mengalami diabetes, yang mengalami preeklampsia yaitu sebanyak 30 responden (52,6\%). Hasil uji statistik chi square, diperoleh $\mathrm{p}$ value $=0,237$ artinya $\mathrm{p}$ value besar dari 0,05 maka Ho ditolak dengan demikian menunjukan bahwa tidak ada hubungan yang signifikan antara diabetes dengan kejadian preeklampsia di RSUD Muhammad Sani Karimun.

Nilai PrevalensiOdds Ratio $(\mathrm{POR})=$ 2,111 dengan nilai Confidence Interval 95\% $(\mathrm{CI})=1,606-2,776$ artinya responden dengan diabetes 2,1 kali berpeluang mengalami preeklampsia dari pada responden yang tidak diabetes.

\section{d) Hubungan Paritas Terhadap Preeklampsia}

Dari jumlah total sebanyak 31 responden dengan paritas sedikit yang mengalami preeklampsia yaitu sebanyak 15 responden $(48,4 \%)$. Sedangkan dari 29 responden dengan paritas banyak, yang mengalami preeklampsia yaitu sebanyak 15 responden $(51,7 \%)$. Hasil uji statistik chi square, diperoleh $\mathrm{p}$ value $=$ 0,000 artinya $\mathrm{p}$ value kecil dari 0,05 maka Ho gagal ditolak dengan demikian menunjukan bahwa ada hubungan yang signifikan antara paritas dengan kejadian preeklampsia di RSUD Muhammad Sani Karimun.

Nilai PrevalensiOdds Ratio $(\mathrm{POR})=$ 6,875 dengan nilai Confidence Interval 95\% $(\mathrm{CI})=3,318-12,410$ artinyaresponden dengan paritas banyak 6,8 kali berpeluang mengalami preeklampsia dari pada responden dengan paritas sedikit.

\section{b. Pembahasan}

\section{1) Hubungan Antara Usia dengan Kejadian Preeklampsia}

Hasil uji statistik chi square, diperoleh $\mathrm{p}$ value $=0,004$ artinya $\mathrm{p}$ value kecil dari 0,05 maka Ho gagal ditolak dengan demikian menunjukan bahwa ada hubungan yang signifikan antara usia dengan kejadian preeklampsia di RSUD Muhammad Sani Karimun. Nilai PrevalensiOdds Ratio $(\mathrm{POR})=$ 5,266 dengan nilai Confidence Interval 95\% $(C I)=2,088-11,807$ artinya responden dengan usia berisiko 5,2 kali berpeluang mengalami preeklampsia dari pada responden dengan usia tidak berisiko.

Penelitian yang dilakukan oleh Langelo, dkk (2013), menunjukan bahwa wanita umur $<20$ tahun dan $>35$ tahun memiliki risiko 3,37 kali dibandingkan wanita umur 20-35 tahun. Selain itu, hasil penelitian Asrianti (2009) menyimpulkan bahwa umur ibu hamil $<20$ tahun dan $>35$ tahun berisiko 3,144 kali 
JURNAL SEHAT MASADA VOLUME XV

mengalami preeklampsia, penelitian Salim (2012) juga menyebutkan usia ibu hamil $<20$ tahun atau $\geq 35$ tahun berisiko 3,615 kali lebih besar untuk mengalami preeklampsia, serta hasil penelitian Ferida (2007) menyimpulkan, ibu hamil dengan usia yang sama berisiko 3,659 kali lebih besar untuk mengalami preeklampsia.

\section{2) Hubungan Antara Kehamilan Ganda dengan Kejadian Preeklampsia}

Hasil uji statistik chi square, diperoleh $\mathrm{p}$ value $=1,000$ artinya $\mathrm{p}$ value besar dari 0,05 maka Ho ditolak dengan demikian menunjukan bahwa tidak ada hubungan yang signifikan antara kehamilan ganda dengan kejadian preeklampsia di RSUD Muhammad Sani Karimun. Nilai PrevalensiOdds Ratio $(\mathrm{POR})=$ 1,000 dengan nilai Confidence Interval 95\% $(\mathrm{CI})=0,131-7,605$ artinya responden dengankehamilan ganda berisiko 1 kali berpeluang mengalami preeklampsia dari pada responden dengan usia kehamilan tunggal.

umur dan paritas terhadap kejadian preeklampsia, sedangkan kehamilan kembar, obesitas dan riwayat diabetes mellitus tidak menunjukkan hubungan yang bermakna dan bukan faktor risiko preeklampsia pada ibu bersalin di RSUP DR. M. Djamil Padang tahun 2013.

Berdasarkan data diatas dapat disimpulkan bahwa kejadian kehamilan ganda jarang ditemukan yang disertai dengan kejadian preeklampsia.Oleh karena itu, tidak terlihat adanya hubungan antara kehamilan ganda dengan kejadian preeklampsia di RSUD Muhammad Sani Karimun.

\section{3) Hubungan Antara Diabetes dengan Kejadian Preeklampsia}

Hasil uji statistik chi square, diperoleh $\mathrm{p}$ value $=0,237$ artinya $\mathrm{p}$ value besar dari 0,05 maka Ho ditolak dengan demikian menunjukan bahwa tidak ada hubungan yang signifikan antara diabetes dengan kejadian preeklampsia di RSUD Muhammad Sani Karimun. Nilai PrevalensiOdds Ratio $(\mathrm{POR})=2,111$ dengan nilai Confidence Interval 95\% $(\mathrm{CI})=1,606$ 2,776 artinya responden dengan diabetes 2,1 kali berpeluang mengalami preeklampsia dari pada responden yang tidak diabetes.

Diabetes merupakan suatu penyakit di mana tubuh tidak menghasilkan insulin dalam jumlah cukup atau sebaliknya, tubuh kurang mampu menggunakan insulin secara maksimal (walaupun jumlah insulin sudah cukup).Kehamilan dapat mempengaruhi timbulnya penyakit diabetes pada seseorang.Sejak kehamilan terjadilah perubahan tingkat karbohidrat dalam tubuh ibu.Hal itu terjadi selama dalam kehamilan diperlukan energi yang lebih dari biasanya bagi pertumbuhan janin.

Hasil penelitian ini sejalan dengan penelitian yang dilakukan oleh Huda Hanum di RSUP DR. M. Djamil Padang pada tahun 2013, terdapat jumlah kasus sebanyak 94 kasus. Dari hasil penelitian menunjukkan ada hubungan umur dan paritas terhadap kejadian preeklampsia, sedangkan kehamilan kembar, obesitas dan riwayat diabetes mellitus tidak 
menunjukkan hubungan yang bermakna dan bukan faktor risiko preeklampsia pada ibu bersalin di RSUP DR. M. Djamil Padang tahun 2013.

Berdasarkan data di atas dapat disimpulkan bahwa kejadian diabetes jarang ditemukan yang disertai dengan kejadian preeklampsia.Oleh karena itu, tidak terlihat adanya hubungan antara diabetes dengan kejadian preeklampsia di RSUD Muhammad Sani Karimun.

\section{4) Hubungan Antara Paritas dengan Kejadian Preeklampsia}

Hasil uji statistik chi square, diperoleh $\mathrm{p}$ value $=0,000$ artinya $\mathrm{p}$ value kecil dari 0,05 maka Ho gagal ditolak dengan demikian menunjukan bahwa ada hubungan yang signifikan antara paritas dengan kejadian preeklampsia di RSUD Muhammad Sani Karimun. Nilai PrevalensiOdds Ratio $(\mathrm{POR})=$ 6,875 dengan nilai Confidence Interval 95\% $(\mathrm{CI})=3,318-12,410$ artinya responden dengan paritas banyak 6,8 kali berpeluang mengalami preeklampsia dari pada responden dengan paritas sedikit.

Berdasarkan data di atas dapat disimpulkan bahwa paritas 3 dan paritas tinggi $>3$ mempunyai angka kematian maternal lebih tinggi, semakin tinggi paritas semakin tinggi kematian maternal. Hal tersebut dikarenakan pada setiap kehamilan terjadi peregangan rahim, jika kehamilan berlangsung terus menerus maka rahim akan semakin melemah sehingga dikhawatirkan akan terjadi gangguan pada saat kehamilan, persalinan, dan nifas.

Jurnal Penelitian Kesehatan STIKes Dharma Husada Bandung

\section{KESIMPULAN}

1. Sebagian besar responden berusia $\leq 20$ tahun atau >35 tahun sebanyak 37 orang $(61,7 \%)$. Sebagian besar responden mengalami kehamilan tunggal sebanyak 56 orang $(93,3 \%)$. Sebagian besar responden tidak mengalami diabetes sebanyak 57 orang $(95 \%)$ dan sebagian besar responden mengalami paritas dalam jumlah yang sedikit $(\leq 2)$ sebanyak 31 orang $(51,7 \%)$. Terdapat hubungan antara usia dengan kejadian preeklampsia pada ibu bersalin di RSUD Muhammad Sani Karimundengan $\mathrm{p}$ value $=0,004$.

2. Tidak ada hubungan antara kehamilan ganda dengan kejadian preeklampsia pada ibu bersalin di RSUD Muhammad Sani Karimundengan $\mathrm{p}$ value $=1,000$.

3. Tidak ada hubungan antara diabetes dengan kejadian preeklampsia pada ibu bersalin di RSUD Muhammad Sani Karimundengan $\mathrm{p}$ value $=0,237$.

4. Terdapat hubungan antara paritas dengan kejadian preeklampsia pada ibu bersalin di RSUD Muhammad Sani Karimundengan $\mathrm{p}$ value $=0,000$.

\section{DAFTAR PUSTAKA}

Aeni, Nurul. 2013. Faktor Risiko Kematian Ibu. Jurnal Kesehatan Masyarakat Nasional Volume 7 Nomor 10. Halaman 453-459

Afdhal, Muh dkk.2012.Faktor Risiko Perencanaan Persalinan Terhadap Kejadian Komplikasi Persalinan di Kabupaten Pinrang Tahun 2012. Jurnal 
Kesehatan Masyarakat Universitas Hasanuddin

Artikasari, Kurniawati. 2009. Hubungan Antara Primigravida dengan Angka Kejadian Preeklampsia/Eklampsia di RSUD Dr. Moewadi Surakarta Periode 1 Januari-31 Desember 2008. Fakultas Kedokteran, Universitas Muhammadiyah Surakarta.

Calallaham, M. dkk.Seri Skema Diagnosis dan Penatalaksanaan Gawat Darurat Medis.

Djannah, Sitti nur dan Ika Sukma Arianti. 2010. Gambaran Epidemiologi Kejadian Preeklampsia/Eklampsia di RSU PKU Muhammadiyah Yogyakarta Tahun 20012009. Jurnal. Buletin Penelitian Sistem Kesehatan. Volume 13.Nomor 4. Oktober 2010:378-385

Hukmiah, dkk. 2013. Faktor yang Berhubungan dengan Pemanfaatan Antenatal Care Di Wilayah Pesisir Kecamatan Mandalle. Epidemiologi Fakultas Kesehatan Masyarakat Universitas Hasanuddin

Lockhart, Anita dan Lyndon Saputra.2014. Asuhan Kebidanan Kehamilan Fisiolologis \& Patologis.Binapura Aksara Publisher. Halaman 13- 15 dan 226

Mansjoer, A. dkk. 2001. Kapita Selekta Kedokteran Edisi Ketiga Jilid Pertama. Jakarta:Media Aesculapius FKUI.
Manuaba, Ida Bagus Gde. 2007. Pengantar Kuliah Obstetri. Jakarta. EGC

Musbikin, I. 2005. Panduan bagi Ibu Hamil dan Melahirkan. Yogyakarta:Mitra Mustaka.

Notoatmodjo, S. (2010).Ilmu Perilaku Kesehatan. Jakarta: Rineka Cipta.

Nuryani., dkk. 2012. Hubungan Pola Makan, Sosial Ekonomi, Antenatal Care dan Karakteristik Ibu Hamil dengan Kasus Preeklampsia di Kota Makassar. Artikel Penelitian. Program Studi Ilmu Gizi, Kesehatan Masyarakat, Universitas Hasanuddin, Makassar.

Prawirohardjo, Sarwono. (2012) Ilmu Kebidanan. Jakarta: PT Bina Pustaka Sarwono Prawirohardjo.

Retnowati, Indah dan Asid Dwi Astuti. 2010. Hubungan penerapan program perencanaan persalinan dan pencegahan komplikasi (P4K) oleh ibu hamil dengan upaya pencegahan komplikasi kehamilan di Puskesmas Sidorejo Kidul Salatiga. Jurnal Kebidanan. Volume II Nomor 02, 2010. Halaman 39-51

Rozikhan. 2007. Faktor-faktor Risiko Terjadinya Preeklampsia Berat di Rumah Sakit Dr. H. Soewondo Kendal. Tesis. Program Studi Magister Epidemiologi Universitas Diponegoro Semarang 